\title{
MECHANICAL PROPERTIES OF A GEOPOLYMER CONCRETE/ULTRAFINE MATERIAL BASED COMPOSITE
}

\author{
MEHANSKE LASTNOSTI KOMPOZITNEGA MATERIALA NA \\ OSNOVI GEOPOLIMERNEGA CEMENTA IN ULTRAFINIH \\ DELCEV PLAVŽNE ŽLINDRE
}

\author{
Vijayasarathy Rathanasalam*, Jayabalan Perumalsami, Karthikeyan Jayakumar \\ Department of Civil Engineering, National Institute of Technology, Tiruchirappalli, Tamil Nadu 620015, India \\ Prejem rokopisa - received: 2020-05-,07; sprejem za objavo-accepted for publication: 2020-08-05
}

doi:10.17222/mit.2020.072

\begin{abstract}
Industrial development leads to numerous slags; therefore, by-products from the industries should be effectively handled. In this novel work, fly ash and crushed-stone sand along with ultrafine ground granulated blast-furnace slag (UFGGBFS) were mixed to study the performance of $10 \mathrm{M}, 12 \mathrm{M}$ and 14M geopolymer concrete. As per Indian standards, the properties of UFGGBFS-incorporated geopolymer concrete (GPC) were examined by testing the flexural strength, compressive strength, water absorption and splitting tensile strength. The values infer that an addition of UFGGBFS and fly ash to GPC stimulates these properties so that the material can be an alternative to conventional concrete. UFGGBFS-based geopolymer concrete improves the densification and interfacial transition zone. An increase in the molarity resulted in a strength gain of all the prepared specimens.

Keywords: crushed-stone sand, fly ash, geopolymer concrete, ultrafine GGBFS, molarity
\end{abstract}

Industrijski razvoj proizvaja vrsto, pogosto tudi, neželenih stranskih produktov, kot so npr. žlindre. Zato je te vrste stranskih produktov, nastalih $\mathrm{v}$ industriji, potrebno učinkovito obdelati oz. po možnosti predelati $\mathrm{v}$ koristen proizvod. $\mathrm{V}$ tej najnovejši raziskavi so avtorji ugotavljali lastnosti $10 \mathrm{M}, 12 \mathrm{M}$ in $14 \mathrm{M}$ geopolimernih betonov, v katere so dodajali določen delež dimniškega pepela, zdrobljenega kamenja in granuliranih ultrafinih delcev zdrobljene plavžne žlindre (UFGGBFS). V skladu z indijskimi standardi so z UFGGBFS obogatenemu geopolimernemu betonu (GPC) določili upogibno, tlačno in cepilno natezno trdnost ter absorpcijo vode. Rezultati raziskave so pokazali, da dodatek UFGGBFS in dimniškega pepela izboljša lastnosti GPC in predstavlja možno alternativno uporabo konvencionalnemu betonu. Geopolimerni kompozitni beton na osnovi UFGGBFS izboljšuje njegovo zgostitev in trdnost $\mathrm{v}$ mejni prehodni coni. Trdnost vseh pripravljenih preizkušancev se je povečevala $\mathrm{Z}$ večanjem molarnosti $(\mathrm{M})$ polimernega betona.

Ključne besede: zdrobljena kamenina, pesek, dimniški pepel, geopolimerni beton, granulirani ultra fini delci zdrobljene plavžne žlindre, molarnost

\section{INTRODUCTION}

Natural resources become depleted during the manufacturing of cement and the atmosphere becomes polluted by greenhouse gases. ${ }^{1}$ Population growth has given rise to an infrastructural growth, creating the demand for effective building materials, especially ordinary Portland cement. About $7 \%$ of carbon-dioxide $\left(\mathrm{CO}_{2}\right)$ emission is caused by the cement industry. ${ }^{2}$ The annual global production of cement in 2050 is expected to be 4.38 billion tones. $^{3}$ A lower consumption of ordinary Portland cement (OPC) can provide for a sustainable environment. To overcome these issues, environmental friendly materials should be made. Low-carbon geopolymers can be used instead of OPC. Test results showed that geopolymers exhibited similar or better properties when compared with OPC. Base materials such as aluminosilicate waste were used in the manufacturing of geopolymer. $\mathrm{CO}_{2}$ emissions and costs were reduced by replacing OPC by aluminosilicate. ${ }^{4}$ Large areas of land are polluted due

*Corresponding author's e-mail:

vijayasarathy.civil@gmail.com (Vijayasarathy Rathanasalam) to disposal of industrial waste, thereby causing an environmental hazard. To overcome these problems, a lot of researchers have worked on alternative materials to enhance the development of new binding materials. One such material is geopolymer concrete, which is alkali activated and includes rich alumina compounds. The GPC made of GGBFS and fly ash showed a good stability and strength. ${ }^{5,6}$ The strength and durability of GPC were far better when compared to ordinary concrete; the GPC performance is superior to that of conventional concrete. $^{7-12}$ Superior mechanical properties were achieved by incorporating fly ash (class F) as the binder during the manufacturing of geopolymer concrete. ${ }^{13-20}$ Geopolymer concrete achieves a good compressive strength when subjected to thermal curing in a range of $60-100{ }^{\circ} \mathrm{C} .{ }^{21-27}$ Many of the published studies stated that the strength performance of low-calcium fly ash subjected to a short-term elevated temperature and ambient curing could not match heat curing. The main reason for it is polymerization, which mainly occurs due to heat resulting in the formation of calcium aluminate silicate hydrate $(\mathrm{CASH})$ along with sodium aluminate silicate hy- 
Table1: Chemical compositions of UFGGBFS and fly ash

\begin{tabular}{|c|c|c|c|c|c|c|c|c|}
\hline Chemical composition & $\mathrm{SiO}_{2}(\%)$ & $\mathrm{Al}_{2} \mathrm{O}_{3}(\%)$ & $\mathrm{Fe}_{2} \mathrm{O}_{3}(\%)$ & $\mathrm{SO}_{3}(\%)$ & $\mathrm{CaO}(\%)$ & $\mathrm{Mgo}(\%)$ & $\mathrm{Na}_{2} \mathrm{O}(\%)$ & $\mathrm{K}_{2} \mathrm{O}(\%)$ \\
\hline CLASS 'F' FLYASH & 62.30 & 27.62 & 4.12 & 0.28 & 1.2 & 0.55 & 0.22 & 1.31 \\
\hline UFGGBFS & 33 & 22 & 1.7 & 0.11 & 34 & 6.0 & - & - \\
\hline
\end{tabular}

Table 2: Specific gravity of GPC materials

\begin{tabular}{|c|c|c|}
\hline S. No. & Material & Specific gravity \\
\hline 1 & UFGGBFS & 2.72 \\
\hline 2 & Fly ash & 2.64 \\
\hline 3 & Fine aggregate & 2.62 \\
\hline 4 & Coarse aggregate & 2.83 \\
\hline
\end{tabular}

Table 3: Mixture proportions for GPC

\begin{tabular}{|c|c|c|c|c|c|c|}
\hline Mix & $\begin{array}{l}\text { Fly ash } \\
\left(\mathrm{kg} / \mathrm{m}^{3}\right)\end{array}$ & $\begin{array}{c}\text { Sodium hydroxide (for } \\
10 \mathrm{M}, 12 \mathrm{M} \text { and } 14 \mathrm{M}) \\
\left(\mathrm{kg} / \mathrm{m}^{3}\right)\end{array}$ & $\begin{array}{l}\text { Sodium silicate } \\
\qquad\left(\mathrm{kg} / \mathrm{m}^{3}\right)\end{array}$ & $\begin{array}{l}\text { Fine aggregate } \\
\qquad\left(\mathrm{kg} / \mathrm{m}^{3}\right)\end{array}$ & $\begin{array}{l}\text { Coarse aggre- } \\
\text { gate }\left(\mathrm{kg} / \mathrm{m}^{3}\right)\end{array}$ & $\begin{array}{c}\text { Super plasticizer } \\
(\%)\end{array}$ \\
\hline UFGGBFS $0 \%$, & 408 & 42 & 105 & 592 & 1257 & 2 \\
\hline UFGGBFS $5 \%$ & 388 & 42 & 105 & 592 & 1257 & 2 \\
\hline UFGGBFS $10 \%$ & 367 & 42 & 105 & 592 & 1257 & 2 \\
\hline
\end{tabular}

drate (NASH). Literature showed us that the heat-cured geopolymer concrete is mainly used in precast structures. Due to these restrictions, the performance of geopolymer concrete at ambient curing should be studied. ${ }^{28}$ Some researchers studied the early-age curing performance of the slag in geopolymer concrete at ambient curing and the results were good. Different characteristics of GPC $(10 \mathrm{M}, 12 \mathrm{M}$ and $14 \mathrm{M})$ are calculated by testing water absorption, flexural, splitting tensile and compressive strength. This paper enumerates the characteristics of ambient-cured GPC made of Class F fly ash and different amounts of UFGGBFS (0, 5, 10 and 15) \% for different concentrations of sodium hydroxide $(\mathrm{NaOH})$.

\section{METHODS AND MATERIALS}

\subsection{Materials used for making GPC}

For the current work, fly ash (F Class) was procured from the thermal plant located at Mettur, Tamilnadu, India, conforming with IS: $3812-2003 .{ }^{29}$ UFGGBFS is a low-calcium silicate micro-fine material with a particle size of $6 \mu \mathrm{m}$ and a specific surface area of $1200 \mathrm{~m}^{2} / \mathrm{kg}$. The strength of GPC is improved due to the ultrafine particle size. ${ }^{30-33}$ When UFGGBFS replaces the binder, it improves the properties of the concrete. The chemical compositions of UFGGBFS and fly ash are shown in Table 1. A graded coarse aggregate with a nominal size of $12.5 \mathrm{~mm}$ conforming with IS $383: 2016^{34}$ and graded crushed-stone sand conforming with IS 2386:1963 35 were mixed in this work. Table 2 shows the specific gravity of GPC materials. Sodium silicate $\left(\mathrm{Na}_{2} \mathrm{SiO}_{3}\right)$ and $\mathrm{NaOH}$ were incorporated in this work as alkaline activators starting an eminent process in geopolymerization. $\mathrm{NaOH}$ pellets (a 98-\% purity) were utilized to make solutions with different molarity values and sodium silicate was commercially procured. To improve the workability of GPC, a naphthalene sulphonate-based superplasticizer acting as a high-range water reducer was used, conforming with IS 9103:1999. ${ }^{36}$ In this work, a dose percentage of $2 \%$ was used to overcome problems of stickiness and cohesiveness.

\subsection{Manufacturing of geopolymer concrete}

GPC mixtures with and without UFGGBFS were studied. Based on the previous work, mixtures were prepared. Some fly ash was replaced with UFGGBFS, in the amounts of $(0,5,10$ and 15$) \% .2 \%$ of the binder content was fixed as the superplasticizer dosage. Table 3 shows different proportions of the mixture.

\subsection{GPC specimen casting and curing}

Preparation of sodium hydroxide was done 24 hours before mixing and it was combined with sodium silicate an hour before the GPC preparation. Using a pan, the mixture of fly ash, UFGGBFS and saturated surface-dry aggregate materials were mixed; the activator solution was added to dry mixture, followed by 5 -minute effective mixing to produce fresh GPC. To enhance the workability, water and superplasticizer were added. A vibrating table was used for compaction. A cube with dimensions of $(15 \times 15 \times 15) \mathrm{cm}$ was cast for a compression-strength test (IS 516:1959) ${ }^{37}$ and water-absorption test (BS1881: Part122, 1983). ${ }^{38}$ A cylinder with a diameter of $15 \mathrm{~cm}$ and a height of $30 \mathrm{~cm}$ was made to find the splitting tensile strength as per IS 5816:1999. ${ }^{39}$ A prism with dimensions of $(500 \times 100 \times 100) \mathrm{mm}$ was made to determine the flexural strength. The curing of the geopolymer-concrete specimens was done in two ways. In the first case where fly ash was used as the only binder, curing was carried out in an oven at $60^{\circ}$. In the second case where fly ash was replaced by $(5,10$ and 
15) $\%$ of UFGGBFS, ambient-temperature curing of the geopolymer-concrete specimens was carried out in the laboratory.

\section{RESULTS AND DISCUSSION}

\subsection{Effect of compressive strength}

The compressive-strength test is widely studied and used to determine mechanical properties. The GPC samples of $(15 \times 15 \times 15) \mathrm{cm}$ were kept between steel plates after cleaning and the standard loading rate $(140 \mathrm{~kg} / \mathrm{sq}$ $\mathrm{cm} / \mathrm{min}$ ) was applied on them. For each case, three identical specimens were made and the testing was done after $7 \mathrm{~d}$ and $28 \mathrm{~d}$, using a compression testing machine. The mean values for the GPC based on UFGGBFS and fly ash are displayed in Figure 1, indicating that the rise in the molarity elevates the performance and strength of the specimen. The compressive-strength values after $7 \mathrm{~d}$ for the $10 \mathrm{M}, 12 \mathrm{M}$ and $14 \mathrm{M}$ GPC were found to be between $24 \mathrm{MPa}$ and $40 \mathrm{MPa}$. The compressive-strength value after $28 \mathrm{~d}$ for the GPC with 15-\% UFGGBFS was $42 \mathrm{MPa}$. These values indicate that the optimum molarity is $14 \mathrm{M}$. The GPC with UFGGBFS is similar to the GPC without UFGGBFS with respect to the strength increase with age. The effect of UFGGBFS with fly ash at $14 \mathrm{M}$ $(\mathrm{NaOH})$ is larger. Additions of $5-\%$ and $10-\%$ UFGGBFS also showed a rise in the strength for all the molarity values. A denser GPC is formed as a result of a

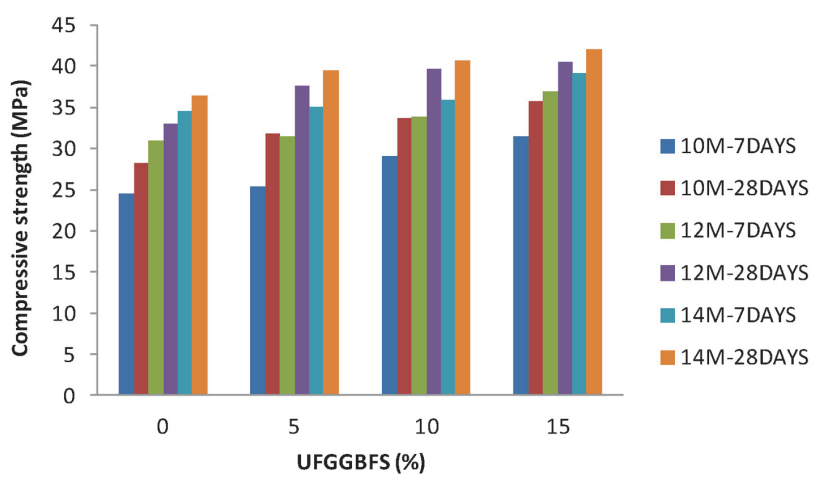

Figure 1: Compressive strength of GPC with UFGGBFS and fly ash

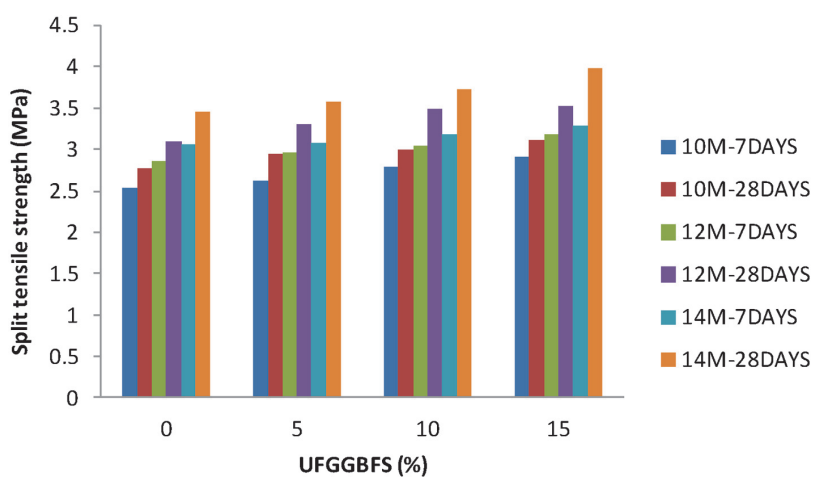

Figure 2: Splitting tensile strength of GPC with UFGGBFS and fly ash higher binder content. The development of binding properties was achieved, thereby increasing the strength. The compressive strength at natural temperature improved due to the existence of calcium in UFGGBFS and fly ash, which is the main cause for the formation of CSH gel apart from CASH and NASH. When the quantity of UFGGBFS is increased, its sources like alumina and silica also increase and as a result, NASH and CASH improve. Thus, due to the polymerization reaction, a higher strength is achieved. After using UFGGBFS, the strength of GPC was improved at ambient temperature; therefore, UFGGBFS can be used to produce GPC as an alternative material. ${ }^{40,41}$

\subsection{Effect of splitting tensile strength}

The splitting tensile strength test started by making cylinders with a radius of $15 \mathrm{~cm}$ and a height of $30 \mathrm{~cm}$. The test was performed over $7 \mathrm{~d}$ and $28 \mathrm{~d}$ by varying the $\mathrm{NaOH}$ molarity and the amount of fly ash. Figure 2 displays the values of the splitting tensile strength. It was found to be between $2.7 \mathrm{MPa}$ and $4 \mathrm{MPa}$ for the GPC cured for $28 \mathrm{~d}$. Amounts of (5, 10 and 15) \% of UFGGBFS caused an increase in the strength when compared to the $10 \mathrm{M}, 12 \mathrm{M}$ and $14 \mathrm{M}$ GPC. From the previous studies, it is known that at a higher temperature, polymerization occurs in GPC, where the alkaline solution reacts with calcium and as a result, heat is developed, which may be the reason for the development of the strength of the UFGGBFS-based GPC. The results clearly show that $\mathrm{NaOH}$ and fly ash with UFGGBFS improve the splitting tensile strength.

\subsection{Effect of flexural strength}

A test of the flexural strength was conducted for the GPC with different $\mathrm{NaOH}$ molarity values and varying percentage of the binder in addition to UFGGBFS after seven and twenty-eight days of curing and the values are displayed in Figure 3. Like the tensile strength and compression strength, flexural strength was found to be increasing with a raise in the $\mathrm{NaOH}$ molarity. The flexural strength was found to be increasing when the molarity increased from $10 \mathrm{M}$ to $12 \mathrm{M}$ and from $10 \mathrm{M}$ to $14 \mathrm{M}$ for

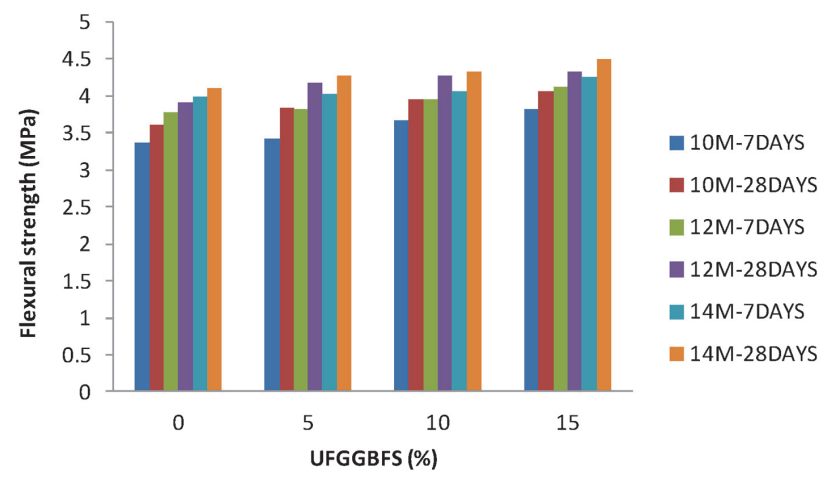

Figure 3: Flexural strength of GPC with UFGGBFS and fly ash 


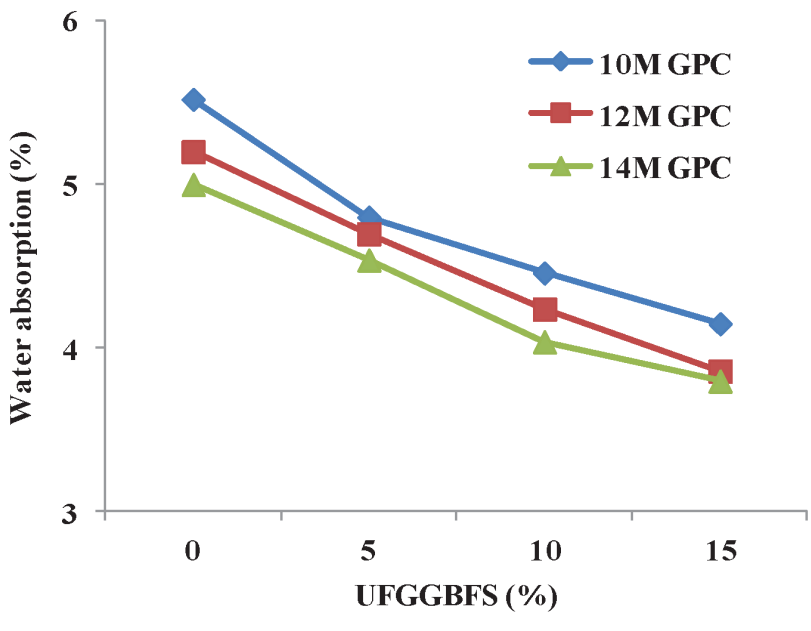

Figure 4: Water-absorption percentage for GPC

the GPC including $(0,5,10$ and 15$) \%$ of UFGGBFS, whereas when comparing all these types, the mixture including $15 \%$ of UFGGBFS showed the best performance. The rise in the molarity along with the rise in the UFGGBFS percentage showed better flexural strength. From the previous work, it is clear that after polymerization, mixtures of UFGGBFS and fly ash result in the formation of a CSH gel..$^{42-45}$ After $28 \mathrm{~d}$ of ambient curing, the microstructure was found to be denser resulting in high strength. ${ }^{46}$

\subsection{Effect of water absorption}

A water-absorption test was performed on GPC to examine the effects of UFGGBFS, fly ash and $\mathrm{NaOH}$ concentration. The testing was done for all the mixes as per the BS Code and the results are shown in Figure 4. The water absorption was found to be higher when the fly-ash quantity increased in the $10 \mathrm{M}, 12 \mathrm{M}$ and $14 \mathrm{M}$ GPC. The water-absorption percentage was found to be decreased for the $5 \%, 10 \%$ and $15 \%$ UFGGBFS when compared to the $0 \%$ UFGGBFS for all the molarity values. The water absorption of all the mixtures was found to be from $3.5 \%$ to $6 \%$. The combination of UFGGBFS and fly ash causes a reduction in the water absorption of GPC. This composite material exhibits geopolymerization. Additional minerals fill in the micropores of GPC. A rise in the $\mathrm{NaOH}$ molarity decreases the water absorption, which may be due to the process of hydration that occurs because of the reaction between the alkaline activator and calcium. The reduction in the water absorption is achieved due to the fineness of UFGGBFS and fly ash.

\section{CONCLUSIONS}

Based on the experimental work on GPC using ultrafine GGBFS, the following conclusion were made:

- The strength properties of GPC based on UFGGBFS and fly ash were found to be improved.
- At ambient temperature, the GPC strength was determined after $7 \mathrm{~d}$ and $28 \mathrm{~d}$ of curing; in addition to polymerization, hydration played an important role in the strength improvement.

- 14-M GPC showed the best performance with respect to the flexural, compressive and tensile strength when compared to $10 \mathrm{M}, 12 \mathrm{M}$.

- The 15-\% addition of UFGGBFS showed good strength for all the molarity values when compared to the other amounts.

- The increase in the amount of UFGGBFS improved the interfacial transition zone of GPC. The water absorption of GPC decreased with an increase in the UFGGBFS amount.

- Using crushed-stone sand and UFGGBFS is environment friendly and hence, the mixture can be used as an innovative material.

\section{REFERENCES}

${ }^{1}$ S. Ahmari, X. Ren, V. Toufigh, L. Zhang, Production of geopolymeric binder from blended waste concrete powder and fly ash, Construction and Building Materials, 35 (2012), 718-729, doi:10.1016/ j.conbuildmat.2012.04.044

${ }^{2} \mathrm{C}$. Meyer, The greening of the concrete industry, Cement and Concrete Composites, 31 (2009), 601-605

${ }^{3}$ M. Schneider, M. Romer, M. Tschudin, H. Bolio, Sustainable cement production present and future, Cement and Concrete Research, 41 (2011), 642-650, doi:10.1016/j.cemconres.2011.03.019

${ }^{4}$ L. K. Turner, F. G. Collins, Carbon dioxide equivalent (CO2-e) emissions: a comparison between geopolymer and OPC cement concrete, Construction and Building Materials, 43 (2013), 125-130, doi:10.1016/j.conbuildmat.2013.01.023

${ }^{5}$ G. Venkata Suresh, P. Pavan Kumar Reddy, J. Karthikeyan, Effect of GGBS and fly ash aggregates on properties of geopolymer concrete, Journal of Structural Engineering,43 (2017)5, 436-444

${ }^{6}$ D. Ravikumar, S. Peethamparan, N. Neithalath, Structure and strength of $\mathrm{NaOH}$ activated concretes containing fly ash or GGBFS as the sole binder, Cement and Concrete Composites, 32 (2010), 399-410, doi:10.1016/j.cemconcomp.2010.03.007

${ }^{7}$ K. Mahendran, N. Arunachelam, Performance of Fly Ash and Copper Slag Based Geopolymer Concrete, Indian Journal of Science and Technology, 9 (2016) 2, 0974-5645

${ }^{8}$ F. N. Okoye, J. Durgaprasad, N. B. Singh, Mechanical properties of alkali activated fly ash/Kaolin based geopolymer concrete, Construction and Building Materials, 98 (2015), 685-691, doi:10.1016/ j.dib.2015.10.029

${ }^{9}$ Mahya Askarian, Zhong Tao, Georgius Adam, Bijan Samali, Mechanical properties of ambient cured one-part hybrid OPC-geopolymer concrete, Construction and Building Materials, 186 (2018), 330-337

${ }^{10}$ A. Karthik, K. Sudalaimani, C. T. Vijaya Kumar, Investigation on mechanical properties of fly ash-ground granulated blast furnace slag based self-curing bio-geopolymer concrete, Construction and Building Materials, 149 (2017), 338-349, doi:10.1016/j.conbuildmat. 2017.05.139

${ }^{11}$ Kamal Neupane, Fly ash and GGBFS based powder-activated geopolymer binders: A viable sustainable alternative of Portland cement in concrete industry, Mechanics of Materials, 103 (2016), 110-122, doi:10.1016/j.mechmat.2016.09.012

${ }^{12}$ F. Collins, J. G. Sanjayan, Workability and mechanical properties of alkali-activated slag concrete, Cement and Concrete Research, 29 (1999) 3, 455-458 
${ }^{13}$ M. Chi, R. Huang, Binding mechanism and properties of alkali-activated fly ash/slag mortars, Construction and Building Materials, 40 (2013), 291-298, doi:10.1016/j.conbuildmat.2012.11.003

${ }^{14}$ M. Albitar, P. Visintin, M. S. Mohamed Ali, M. Drechsler, Assessing behaviour of fresh and hardened geopolymer concrete mixed with class-F fly ash, KSCE Journal of Civil Engineering, 19 (2015) 5, 1445-1455, doi:10.1007/s12205-014-1254-Z

${ }^{15}$ N. Bouzoubaâ, M. H. Zhang, V. M. Malhotra, Mechanical properties and durability of concrete made with high-volume fly ash blended cements using a coarse fly ash, Cement and Concrete Research, 31 (2001) 10, 1393-1402

${ }^{16}$ Suman Saha, C. Rajasekaran, Enhancement of the properties of fly ash based geopolymer paste by incorporating ground granulated blast furnace slag, Construction and Building Materials, 146 (2017) 15, 615-620, doi:10.1016/j.conbuildmat.2017.04.139

${ }^{17}$ H. Yildirim, M. Sümer, V. Akyüncü, E. Gürbüz, Comparison on efficiency factors of $\mathrm{F}$ and $\mathrm{C}$ types of fly ashes, Construction and Building Materials, 25 (2011) 6, 2939-2947, doi:10.1016/j.conbuildmat. 2010.12.009

${ }^{18}$ D. Hardjito, B. V. Rangan, Development and properties of low-calcium fly ash based geopolymer concrete, In: Research Report GC 1, Perth, Australia, Curtin University of Technology, 2005

${ }^{19}$ M. Olivia, H. Nikraz, Properties of fly ash geopolymer concrete designed by Taguchi method, Materials \& Design, 36 (2012), 191-198, doi:10.1016/j.matdes.2011.10.036

${ }^{20}$ A. Palomo, A. Fernández-Jiménez, G. Kovalchuk, L. M. Ordoñez, M. C. Naranjo, OPC fly ash cementitious systems: study of gel binders produced during alkaline hydration, Journal of Materials Science, 42 (2007) 9, 2958-2966, doi:10.1007/s10853-006-0585-7

${ }^{21}$ A. Palomo, M. W. Grutzeck, M. T. Blanco, Alkali-activated fly ashes, cement for the future, Cement and Concrete Research, 29 (1999) 8, 1323-1329, doi:10.1016/S0008-8846 (98)00243-9

${ }^{22}$ G. Kovalchuk, A. Fernandez-Jimenez, A. Palomo, Alkali-activated fly ash: Effect of thermal curing conditions on mechanical and microstructural development - Part II, Fuel, 86 (2007) 3, 315-322, doi:10.1016/j.fuel.2006.07.010

${ }^{23}$ T. Bakharev, Geopolymeric materials prepared using class F fly ash and elevated temperature curing, Cement and Concrete Research, 35 (2005) 6, 1224-1232, doi:10.1016/j.cemconres.2004.06.031

${ }^{24}$ F. Puertas, S. Martinez-Ramirez, S. Alonso, T. Vázquez, Alkali-activated fly ash/slag cements: Strength behaviour and hydration products, Cement and Concrete Research, 30 (2000) 10, 1625-1632, doi:10.1016/S0008-8846(00)00298-2

${ }^{25}$ A. Brough, A. Atkinson, Sodium silicate-based, alkali-activated slag mortars: Part I. Strength, hydration and microstructure, Cement and Concrete Research, 32 (2002) 6, 865-879, doi:10.1016/S00088846(02)00717-2

${ }^{26}$ J. W. Phair, J. S. J. Van Deventer, Effect of the silicate activator $\mathrm{pH}$ on the microstructural characteristics of waste-based geopolymers, International Journal of Mineral Processing, 66 (2002), 121-143, doi:10.1016/S0301-7516(02)00013-3

${ }^{27}$ J. L. Provis, G. C. Lukey, J. S. J. van Deventer, Do geopolymers actually contain nanocrystalline zeolites? A re-examination of existing results, Chemistry of Materials, 17 (2005), 3075-3085, doi:10.1021/ cm050230i

${ }^{28}$ Parveen Jangra, Dhirendra Singhal, M. Talha Junaid, Bharat Bhushan Jindal, Ankur Mehta, Mechanical and microstructural properties of fly ash based geopolymer concrete incorporating alccofine at ambient curing, Construction and Building Materials, 180 (2018), 298-307, doi:10.1016/j.conbuildmat.2018.05.286
${ }^{29}$ IS: 3812 (Part 1) - 2003, Indian Standards Specification for Pulverized Fuel Ash

${ }^{30}$ Parveen Jangra, D. Singhal, B. B, Jindal, Preparation of geopolymer concrete (GPC) using high-silica rice husk ash (RHA) incorporating alccofine, Advanced Science, Engineering and Medicine, 9 (2017) 5, 370-376, doi:10.1166/asem.2017.1993

${ }^{31}$ B. B. Jindal, D. Singhal, S. K. Sharma, D. K. Ashish, Parveen Jangra, Improving compressive strength of low calcium fly ash geopolymer concrete with alccofine, Advances in Concrete Construction, 5 (2017) 1, 17-29, doi:10.12989/acc.2017.5.1.17

${ }^{32}$ Parveen Jangra, D. Singhal, B. B. Jindal, Experimental study on geopolymer concrete prepared using high-silica RHA incorporating alccofine, Advances in Concrete Construction, 5 (2017) 4, 345-358, doi:10.12989/acc.2017.5.4.345

${ }^{33}$ B. B. Jindal, D. Singhal, Parveen Jangra, Prediction of mechanical properties of alccofine activated low calcium fly ash based geopolymer concrete, ARPN Journal of Engineering and Applied Sciences, 12 (2017) 9

${ }^{34}$ IS: 383-2016. Indian Standard Specification for Coarse and Fine Aggregate for Concrete

${ }^{35}$ IS: 2386 (Part I)-1963 (Reaffirmed 1999). Indian Standard Methods of Test for Aggregates for Concrete

${ }^{36}$ IS: 9103:1999. Indian Standard Specification for Concrete Admixtures

${ }^{37}$ IS: 516-1959 (Reaffirmed 2004). Indian Standard Methods of Tests for Strength of Concrete

${ }^{38}$ BS: 1881-122-1983. British Standard Testing concrete. Method for determination of water absorption

${ }^{39}$ IS 5816:1999 (Reaffirmed 2004). Indian Standard Splitting Tensile Strength of Concrete - Method of Test

${ }^{40}$ G. S. Manjunatha, K. Radhakrishna, K. Venugopal, S. V. Maruthi, Strength characteristics of open air cured geopolymer concrete, Transactions of the Indian Ceramic Society, 73 (2014) 2, 149-156, doi:10.1080/0371750X.2014.923330

${ }^{41}$ Ardra Mohan, K. M. Mini, Strength and durability studies of SCC incorporating silica fume and ultrafine GGBS, Construction and Building Materials, 171 (2018), 919-928

${ }^{42}$ P. S. Deb, P. Nath, P. K. Sarker, The effects of ground granulated blast-furnace slag blending with fly ash and activator content on the workability and strength properties of geopolymer concrete cured at ambient temperature, Materials and Design, 62 (2014), 32-39, doi:10.1016/j.matdes.2014.05.001

${ }^{43}$ B. B. Jindal, D. Singhal, S. Sharma, Parveen, Enhancing mechanical and durability properties of geopolymer concrete with mineral admixture, Computers and Concrete, 21 (2018) 3, 345-353, doi:10.12989/cac.2018.21.3.000

${ }^{44}$ P. Chindaprasirt, T. Chareerat, S. Hatanaka, T. Cao, High-strength geopolymer using fine high-calcium fly ash, Journal of Materials in Civil Engineering, 23 (2011) 3, 264-270, doi:10.1061/(ASCE)MT. 1943-5533.0000161

${ }^{45}$ C. K. Yip, G. C. Lukey, J. L. Provis, J. S. van Deventer, Effect of calcium silicate sources on geopolymerisation, Cement and Concrete Research, 8 (2008) 4, 554-564, doi:10.1016/j.cemconres.2007.11. 001

${ }^{46}$ R. Vijayasarathy, P. Jayabalan, J. Karthikeyan, Effect of Ultrafine Ground Granulated Blast-Furnace Slag (UFGGBFS) and Copper Slag on Ambient Cured Geopolymer Concrete, Annales de Chimie Science des Matériaux, 43 (2019) 6, 377-382, doi:10.18280/ acsm. 430603 